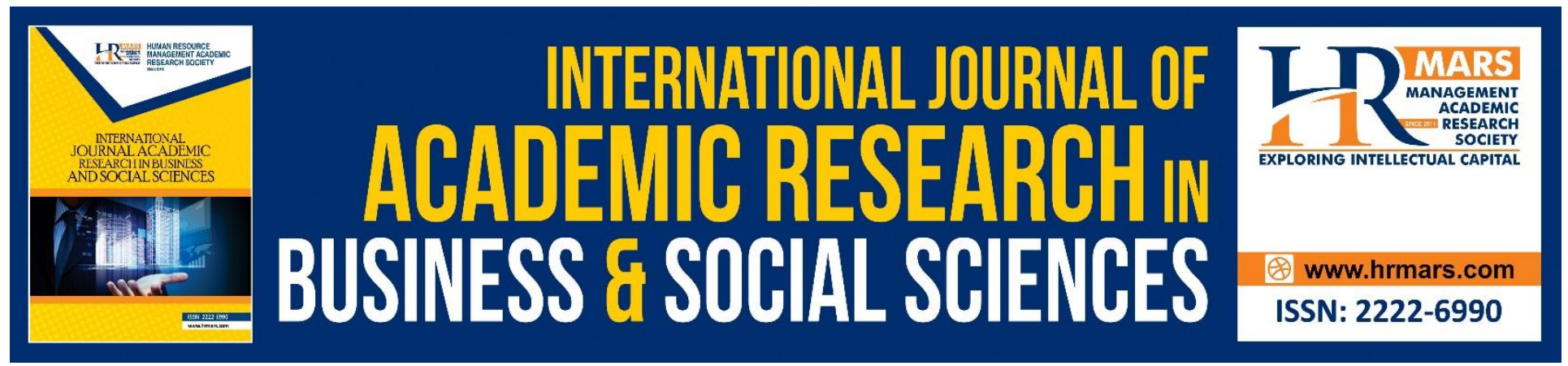

\title{
Factors Influencing Individual Financial Resilience in facing Economic Crisis: Does Financial Literacy really help?
}

Naffisah Mohd Hassan, Erne Suzila Kassim, Siti Noorsuriani Ma'on

To Link this Article: http://dx.doi.org/10.6007/IJARBSS/v8-i11/5284 DOI: $10.6007 /$ IJARBSS/v8-i11/5284

Received: 28 Oct 2018, Revised: 17 Nov 2018, Accepted: 30 Nov 2018

Published Online: 03 Dec 2018

In-Text Citation: (Hassan, Kassim, \& Ma'on, 2018)

To Cite this Article: Hassan, N. M., Kassim, E. S., \& Ma'on, S. N. (2018). Factors Influencing Individual Financial Resilience in facing Economic Crisis: Does Financial Literacy really help? International Journal of Academic Research in Business and Social Sciences, 8(11), 1613-1623.

Copyright: (C) 2018 The Author(s)

Published by Human Resource Management Academic Research Society (www.hrmars.com) This article is published under the Creative Commons Attribution (CC BY 4.0) license. Anyone may reproduce, distribute, translate and create derivative works of this article (for both commercial and non-commercial purposes), subject to full attribution to the original publication and authors. The full terms of this license may be seen at: $\underline{\text { http://creativecommons.org/licences/by/4.0/legalcode }}$

Vol. 8, No. 11, 2018, Pg. 1613 - 1623

Full Terms \& Conditions of access and use can be found at http://hrmars.com/index.php/pages/detail/publication-ethics 


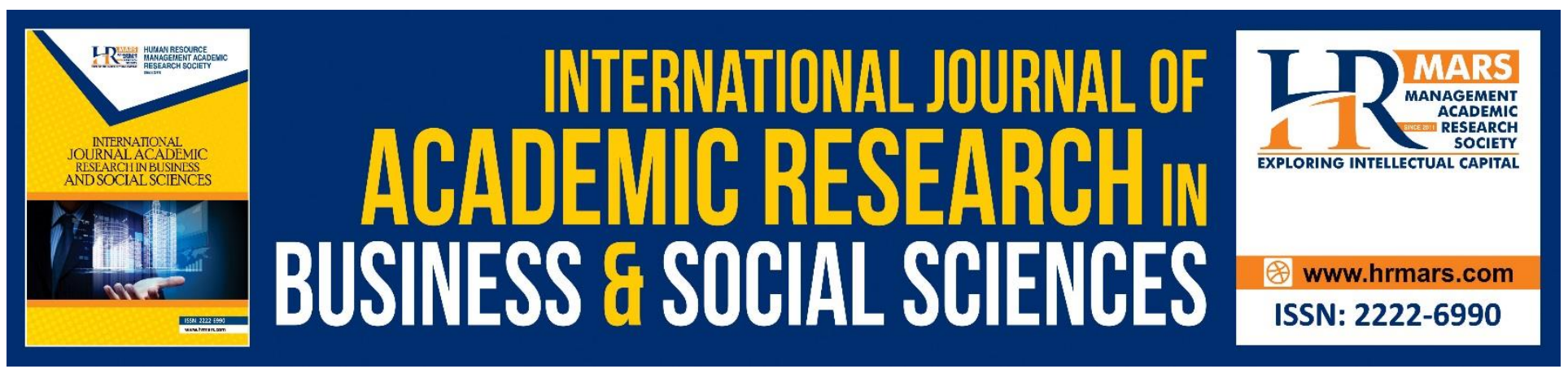

\title{
Factors Influencing Individual Financial Resilience in facing Economic Crisis: Does Financial Literacy really help?
}

\author{
Naffisah Mohd Hassan, Erne Suzila Kassim, Siti Noorsuriani Ma'on \\ Faculty of Business and Management, Universiti Teknologi MARA Cawangan Selangor, \\ Kampus Puncak Alam, 42300 Selangor, MALAYSIA \\ Email:naffi885@puncakalam.uitm.edu.my
}

\begin{abstract}
Economic crisis is a global phenomenon. When the cycle hits, many people are affected. However, the intensity of the effect may vary from one person to another, depending on the individual financial resilience. This study seeks to empirically examine what factors of financial literacy contribute to individual financial resilience in facing economic changes during economic crisis. A correlational study with cross-sectional research design and a survey as a method of data collection were used. A total of 200 completed questionnaires were obtained and only 197 data was valid for data analysis. The findings indicate while all factors relating to financial literacy investigated were significantly associated with individual resilience, the results of the regression test indicate only preference for numerical information and need for cognition were found to be significantly contribute to the individual financial resilience during economic crisis. Therefore, financial literacy is vital to be absorbed in every individual to build resilience towards economic changes during the economic crisis.
\end{abstract} Keywords: Resilience, Economic crisis, Society readiness, Financial Literacy, Mental Health

\section{INTRODUCTION}

The world is changing rapidly. Donald Trump has been officially elected as the next American President by the people. The presidential election triggers changes to the world economy. New technological innovations are rising that lead to fluctuations in the prices of energy. They affect the world economy. Information and communication technology are changing the society. Social media and social networking play a great role in influencing political reform, business trends, teenagers' behavior and family relationships. While there are debates on the good and bad sides of the changes, two main concerns are on the rising rate of unemployment including job security, income inequality and debts, and changes to the social integrations. 
History has shown the relationship between economic turbulence and mental health (WHO, 2011 \& Berkman, Brissette and Seeman, 2000). While reports have shown the important roles of social support to the society during economic crisis (Gili et al., 2013 \& Karanikolos et al., 2013), it is not of less important for a person to be resilience to face the challenges (Evans and Reid, 2014). However, research in financial resilience shows more focus is emphasized on the organizational resilience, rather than personal capability to cope with economic changes (Pal, Torstensson, and Mattila, 2014 \& MacKinnon and Derickson, 2013). Similarly, financial literacy has been a subject of investigation in many studies. However, most studies focus the subject as either from the education perspective (Fernandes, Lynch and Netemeyer 2014), a descriptive study (Almenberg and Dreber 2015) or how it relates to retirement plan (Boisclair, Lusardi and Michaud 2017). As financial literacy is the essence of being financially knowledgable, how it determines financial resilience is the topic of interest.

Therefore, it is of the interest of the researchers to examine the factors influencing the individual financial resilience in coping with the changes. Specifically, the research attempts to answer the question of do numerical information, attitude towards money, need for cognition and planning for money determine individual financial resilience during economic crisis?

\section{REVIEW OF LITERATURE}

\section{Individual Resilience}

Resilience is a process that involves knowledge and experience (Abdul Manaf et al. 2013). This is consistent with Luthar et al. (2000), whose work is cited in Campbell-Sills et al. (2005) that resilience is "a dynamic process wherein individuals display positive adaptation despite the experiences of significant adversity or trauma". Early studies on resilience focused on theory development that emphasized on positive outcomes in the face of adversity. Since resilience is a dynamic process, developing a comprehensive understanding of resilience across the lifespan is potentially important. Therefore, resilience has been studied for different age groups, for instances early childhood (Masten \& Gewirtz, 2006), adolescences (Fergus \& Zimmerman, 2005) and elderly (Adams et al. 2004). While all these groups are significant to be studied, attention should be placed for young adults as youths at this age category are spiritually fragile and tend to be influenced easily. Additionally, Schwartz et al. (2007) highlighted that adolescence is a critical stage of one's life as it is a time of both great opportunity and great risks which include started to think about the future and make positive contributions to their own lives. While at the same time, problems started to appear and depending on how much protection they receive, they can easily be drawn into delinquency and unhealthy activities. Hosseini et al (2010) pointed that this stage is an important period for the development of preventive interventions which are designed to lead to the development of more serious psychopathology in adulthood.

\section{Financial Literacy}

Few studies had been done regarding the correlation factors of financial literacy such as a) Preference for numerical information, b) Attitude toward money, c) Need for cognition, d) Planning for money (long term) to determine the role of individual resilience in assessing financial literacy on facing economic changes during economic crisis. 
Preference for numerical information (PNI) can be defined as "a preference or proclivity toward using numerical information and engaging in thinking involving numerical information" (Viswanathan, 1993). He had developed a scale to measure this construct through a series of studies in an attempt to prove what he believes to be an overlooked aspect of students' and consumers' basic attitude toward numerical information. According to Viswanathan (1993), attitude toward numerical information is likely to influence people so that they will involve in activities or situations where numbers are involved.

Attitudes towards money can be defined as our beliefs about money and money attitude is our way of thinking about money (Ray, 2009). As we all know, everyone has an attitude towards money and for some people, money is a central issue, for others money is just a tool, yet some use money to control things and people. How we perceive money will heavily depend on our childhood and the environment you grew up in. Our past experience and environment is the biggest factor to our money attitude, the good news is that money attitude is a learned behaviour and what is learned can be unlearned.

Need for cognition can be defined as a need to structure a relevant situation in meaningful, integrated ways and a need to understand and make reasonable the experiential world (Cohen, 1957). The higher need for cognition is associated with increased appreciation of debate, idea evaluation, and problem solving.

Planning for money can be defined as comprehensive evaluation of an individual's current pay and future financial state by using current known variables to predict future income, asset values and withdrawal plans. Making arrangements for our cash can be characterize as a far-reaching assessment of a person's present pay and future monetary state by utilizing current known factors to anticipate future wage, resource esteems and withdrawal plans (Fernandes, Lynch and Netemeyer, 2013).

Creating financial literacy intervention is an obvious and a common-sense response to the increased complexity of the financial world. Financial literacy is an important issue at all income levels. The consumers that had higher income level could be prey to predatory advisers and older people with significant wealth could have communication disabilities and may not understand the current rules. Financial literacy also important for low-income or disadvantaged group to deal with the support services for example the financial counselling. Existing research had generally concluded that the financial satisfaction is an outcome of financial literacy. For example, if someone had higher financial literacy they can improves their financial satisfaction by helping individuals develop savings goals, save money, control finances and estate-plan (Loibi, 2005). In contrast, there were also some researchers said that financial dissatisfaction can lead to a greater financial literacy over time. The trauma made by the financial dissatisfaction can disturb someone psychological deleterious and can create financial dissatisfaction (Vinokur, 2002). 
INTERNATIONAL JOURNAL OF ACADEMIC RESEARCH IN BUSINESS AND SOCIAL SCIENCES

Vol. 8, No. 11, Nov, 2018, E-ISSN: 2222-6990 @ 2018 HRMARS

Figure 1: Conceptual model on the relationships between financial literacy and individual resilience during economic crisis.

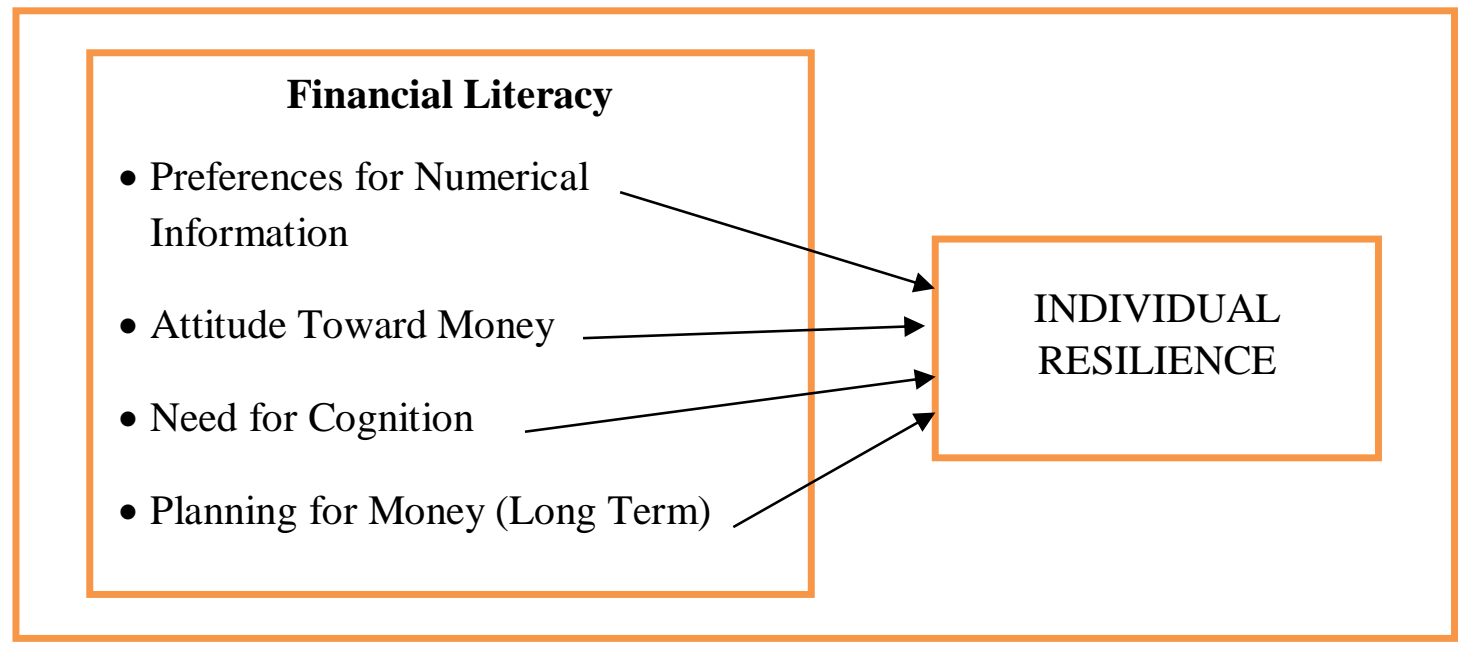

Based on the discussion and model, the following hypotheses were offered:

$\mathrm{H} 1$ : There is a positive relationship between preference for numerical information and individual resilience

$\mathrm{H} 2$ : There is a positive relationship between attitude for money and individual resilience

$\mathrm{H} 3$ : There is a positive relationship between need for cognition and individual resilience

$\mathrm{H} 4$ : There is a positive relationship between planning for money and individual resilience

\section{METHODOLOGY}

Descriptive and correlation research designs were used in this research study. Quantitative survey will be mainly employed. The quantitative method was to provide greater validity of the instrument used. The target population of this study is adults aged between $18-70$ years. A total number of respondents will be 200 for survey method. Convenient sampling was used as the sampling technique. A set of survey question was distributed to the respondents. A well-established questionnaire from Fernandes, Lynch and Netemeyer (2013) and Hildon, Montgomery, Blane, Wiggins and Netuveli, (2009) was used. The questionnaire is designed to examine the relationships between financial literacy and resilience variables.

A total of 200 questionnaires were distributed and 197 with valid data was analyzed using statistical software (IBM SPSS version 21) through descriptive and inferential statistics. This provides greater validation and conformation of the variables tested and creates a foundation for drawing conclusions about the relationship between the variables. Table 1 shows Cronbach's Alpha value for preference for numerical information at 0.844 . Attitude toward money was 0.885 , need for cognition was 0.649 and planning for money (long term) was 0.929 while Resilience obtained .764 . 
INTERNATIONAL JOURNAL OF ACADEMIC RESEARCH IN BUSINESS AND SOCIAL SCIENCES

Vol. 8, No. 11, Nov, 2018, E-ISSN: 2222-6990 @ 2018 HRMARS

Table 1: Reliability Result of Cronbach's Alpha

\begin{tabular}{lccc}
\hline \multicolumn{1}{c}{ Variable } & Cronbach's Alpha & No of Items & Mean Score \\
\hline $\begin{array}{l}\text { Preference for Numerical } \\
\text { Information (NI) }\end{array}$ & .844 & 5 & 3.57 \\
Attitude Toward Money (ATM) & .884 & 6 & 3.87 \\
Need for Cognition (NFC) & .649 & 5 & 2.86 \\
$\begin{array}{l}\text { Planning for Money_Long Term } \\
\text { (PFM) }\end{array}$ & .929 & 6 & 3.83 \\
Resilience & & & \\
Total items & .764 & 12 & 3.54 \\
\hline
\end{tabular}

\section{RESULTS AND DISCUSSION}

A total of 197 questionnaires were valid for data analysis. Table 2 describes the demographic background of the respondents. The study results found that more than half of the respondents were female $(67 \%, n=132)$, while male respondents were $33 \%(n=33)$. Nearly $76 \%$ of the respondents were between 20 and 29 years ( $n=149)$. Less than $20 \%$ were at range age of 30 to 39 years $(n=31)$ and only $9 \%$ was above 40 years $(n=17)$. The study results demonstrate that nearly $70 \%$ of the respondents were single $(n=132), 26 \%$ were married with kids $(n=51)$, married without kids $(6 \%, n=11)$. In terms of monthly income, more than half of the respondents received between RM1000 to RM 2999 $(56.9 \%, n=112)$ and only $5.5 \%(n=11)$ received above RM6000. Less than half of the respondents earn side income $(42.1 \%, n=83)$. At average, the respondents spent over RM350 in a month. The respondents agree that they spent money mostly for food $(53 \%, n=105)$, followed by house $(18 \%)$, health (13\%), shopping (17\%) and car (14\%). 
INTERNATIONAL JOURNAL OF ACADEMIC RESEARCH IN BUSINESS AND SOCIAL SCIENCES

Vol. 8, No. 11, Nov, 2018, E-ISSN: 2222-6990 @ 2018 HRMARS

Table 2: Demographic background of the Respondents ( $n=197)$

\begin{tabular}{|c|c|c|c|}
\hline Variable & & Frequency (n) & Percentage (\%) \\
\hline \multirow{2}{*}{ Gender } & Male & 65 & 33 \\
\hline & Female & 132 & 67 \\
\hline \multirow[t]{3}{*}{ Age range } & $20-29$ & 149 & 75.6 \\
\hline & $30-39$ & 31 & 15.7 \\
\hline & Over 40 years & 17 & 8.6 \\
\hline \multirow[t]{4}{*}{ Marital status } & Single & 132 & 67 \\
\hline & $\begin{array}{l}\text { Married with } \\
\text { kids }\end{array}$ & 51 & 25.9 \\
\hline & $\begin{array}{l}\text { Married without } \\
\text { kids }\end{array}$ & 11 & 5.6 \\
\hline & Single parents & 3 & 1.5 \\
\hline \multirow[t]{5}{*}{ Monthly income } & Below RM99 & 38 & 19.3 \\
\hline & $\begin{array}{l}\text { RM1000 - } \\
\text { RM2999 }\end{array}$ & 112 & 56.9 \\
\hline & RM3000 - RM5999 & 36 & 18.3 \\
\hline & RM6000 - RM8999 & 6 & 3 \\
\hline & $\begin{array}{l}\text { RM9000 and } \\
\text { above }\end{array}$ & 5 & 2.5 \\
\hline \multirow[t]{2}{*}{ Side Income } & Yes & 83 & 42.1 \\
\hline & No & 114 & 57.9 \\
\hline \multirow[t]{5}{*}{$\begin{array}{l}\text { Monthly Average } \\
\text { Spending }\end{array}$} & Below RM49 & 6 & 3 \\
\hline & RM50 - RM149 & 28 & 14.2 \\
\hline & RM150 - RM249 & 30 & 15.2 \\
\hline & RM250 - RM349 & 35 & 17.8 \\
\hline & $\begin{array}{l}\text { RM350 and } \\
\text { above }\end{array}$ & 98 & 49.7 \\
\hline \multirow[t]{5}{*}{ Spending } & Food & 105 & 53.3 \\
\hline & House & 36 & 18.3 \\
\hline & Car & 14 & 7.1 \\
\hline & Shopping & 17 & 8.6 \\
\hline & Health & 25 & 12.7 \\
\hline
\end{tabular}

Financial literacy was measured in terms of preference for numerical information, attitude for money, need for cognition and a long term financial planning. The study results showed that the overall financial literacy level is considered moderately high $(M=3.56, S D=0.47)$; while the individual resilience is considered as an average level $(M=3.53, S D=0.59)$. The respondents assessed their financial literacy level in terms of preference for numerical information ( $M=3.57, S D=0.78)$, attitude for money $(M=3.87, S D=0.74)$ and long term financial planning $(M=3.83, S D=0.66)$, as moderately high level. However, the respondents considered their need for cognition as at average level $(M=2.86$, 
$\mathrm{SD}=0.68)$. These results support the study of Hall (2008), in which the study revealed that individual resilience has been investigated as an important value in a person is to improve their chance of achieving their financial goals (Hall, 2008). Other than that, setting financial goals and always looking for the budget for the next future can get a better view of spending (Fernandes, Lynch, Netemeyer, 2014). When an emergency hits and individual do not have money to cover it, it is easy to wind up falling behind on other bills or worse (Allen, 2016). The good way to avoid these problems is to have so-called emergency cash or saving put aside. Besides that, to launch long term savings plan, individual should add an emergency fund to the list (Allen, 2016). Furthermore, the result that the relationship between planning for money (long term) and the role of individual resilience in assessing society readiness on facing economic changes during economic crisis are more satisfy with their financial goal and feel better to have finances planned out for the future.

Moreover, a correlation analysis was performed to investigate the relationships between financial literacy and individual resilience. Research findings are presented in Table 3 . The data result shows that the financial literacy and individual resilience have a positive relationship $(r=0.46, p<0.01)$. It was found that there were significant positive correlations between individual resilience and every factor of the financial literacy; in which preference for numerical information $(r=0.33, p<0.01)$, attitude for money $(r=0.34, p<0.01)$, need for cognition $(r=0.13, p<0.01)$ and long term financial planning $(r=0.46, p<0.01)$. People in low need for cognition tends to not to do a lot of thinking and rely on stereotypes alone. Furthermore, the result shows of Pearson correlation which indicated a strong relationship correlation between planning for money (long term) and individual resilience. Overall, the results imply that the higher level of financial literacy of the respondents is, the higher their individual resilience becomes.

Table 3: Correlation between Financial Literacy Factors and Individual Resilience ( $\mathrm{n}=197)$

\begin{tabular}{llccccc}
\hline No & \multicolumn{1}{c}{ Variable } & 1 & 2 & 3 & 4 & 5 \\
\hline & Numerical & & & & & \\
1 & Information & -- & & & & \\
& Attitude toward & & & & & \\
2 & Money & $.324^{* *}$ & -- & & & \\
3 & Need for Cognition & $-.147^{*}$ & -.113 & -- & & \\
4 & Planning for Money & $.305^{* *}$ & $.725^{* *}$ & $-.122^{*}$ & -- & - \\
5 & Resilience & $.327^{* *}$ & $.343^{* *}$ & $.131^{*}$ & $.325^{* *}$ & - \\
\hline
\end{tabular}

** Correlation is significant at the 0.01 level (1-tailed).

* Correlation is significant at the 0.01 level (1-tailed).

According to Roberts (1999), money is an essential part of the employment, but it is more than just an economic standard of exchange. Money affects individual needs, emotions, and selfperception. Individual holds a variety of attitudes towards money. Given that money affects many areas of our lives it is important for individual to have a good understanding of our money attitude.

A multiple regression was performed to examine if the factors of financial literacy predicted the level of individual resilience towards economic changes during economic crisis. Using the enter 
method, it was found that the model is significant $(F(4,192)=13.45, p<0.001)$. The $R^{2}$ of 0.22 indicates that only $22 \%$ of the variance in the individual resilience can be explained by the factors of financial literacy; including preference for numerical information, attitude toward money, need for cognition and planning for money in a long term, to be possessed in facing economic changes during economic crisis. Moreover, preference for numerical information (Beta $=0.26, \mathrm{t}(196)=3.744, \mathrm{p}<0.001$ ) and need for cognition (Beta $=0.21, \mathrm{t}(196)=3.19 \mathrm{p}<0.05$ ) significantly predict the individual resilience towards economic changes during economic crisis.

Table 4: Summary of Multiple Regression Statistics for Predictor Variables

\begin{tabular}{lccccc}
\hline Variable & B & SEB & $\beta$ & $t$ & $p$ \\
\hline Preference for Numerical & .195 & .052 & .256 & 3.744 & .000 \\
Information & .147 & .076 & .182 & 1.946 & .053 \\
Attitude for Money & .182 & .057 & .207 & 3.194 & .002 \\
Need for Cognition & .110 & .073 & .140 & 1.500 & .135 \\
Planning for Money in a Long & & & & \\
Term
\end{tabular}

a. Dependent Variable:

Resilience

The results of the regression test provide the evidence for the importance of financial literacy in determining individual financial resilience. Comparing among the financial literacy constructs, preference for numerical information and need for cognition are the two significant determinants. Moreover, in this study, preference for numerical information seems to be stronger than need for cognition in their relationships to financial resilience. What it suggests is those who enjoy numbers, feel satisfied to solve problems that involve numbers and perceive numerical information as very useful in every day, would be more financially resilience during economic crisis. On another note, those who prefer challenging thinking than little thought and feel more satisfied with thinking hard have an advantage during economic crisis. This is because, they have the traits for need for cognition, which is important for determining the individual financial resilience.

\section{CONCLUSION}

The findings indicated that all factors relating to financial literacy investigated were significantly associated with individual resilience. The factors of preference for numerical information and need for cognition were found significantly contribute to the individual resilience during economic crisis. Therefore, financial literacy is vital to be absorbed in every individual to build resilience towards economic changes during economic crisis. It helps individual to manage their financial affairs and improve their standard of living. Besides that, as the contemplate ways of the role individual resilience on facing economic changes in Malaysia, overlook for financial behavior of individual on how spend on the money to raise financial literacy. 
INTERNATIONAL JOURNAL OF ACADEMIC RESEARCH IN BUSINESS AND SOCIAL SCIENCES

Vol. 8, No. 11, Nov, 2018, E-ISSN: 2222-6990 @ 2018 HRMARS

\section{ACKNOWLEDGEMENTS}

The authors gratefully acknowledge the help of Universiti Teknologi MARA in providing the Research Grant Scheme Fund (Project Number: 600-IRMI/MYRA 5/3/BESTARI (038/2017) and Faculty of Business and Management for supporting the research work.

\section{REFERENCES}

Allen, R. E. (2016). Financial crises and recession in the global economy. Edward Elgar Publishing.

Almenberg, J., \& Dreber, A. (2015). Gender, stock market participation and financial literacy. Economics Letters, 137, 140-142.

Berkman, L. F., Glass, T., Brissette, I., \& Seeman, T. E. (2000). From social integration to health: Durkheim in the new millennium. Social science \& medicine, 51(6), 843-857.

Boisclair, D., Lusardi, A., \& Michaud, P. C. (2017). Financial literacy and retirement planning in Canada. Journal of Pension Economics \& Finance, 16(3), 277-296.

Cacioppo, John T.; Petty, Richard E. (1982). "The need for cognition". Journal of Personality and Social Psychology. 42 (1): 116-131. doi:10.1037/0022-3514.42.1.116

Evans, B., \& Reid, J. (2014). Resilient life: The art of living dangerously. John Wiley \& Sons.

Fergus, S. and Zimmerman, M. A. (2005). Adolescent resilience: A framework for understanding healthy development in the face of risk. Annu. Rev. Public Health, 26, 399-419.

Fernandes, D., Lynch, J. G., \& Netemeyer, R. G. (2014). Financial Literacy, Financial Education, and Downstream Financial Behaviors. Management Science, 60(8), 1861-1883. doi:10.1287/mnsc.2013.1849

Gerards, R., \& Welters, R. (2016). Impact of financial pressure on unemployed job search, job find success and job quality. GSBE Research Memoranda, (022).

Gili, M., Roca, M., Basu, S., McKee, M., \& Stuckler, D. (2013). The mental health risks of economic crisis in Spain: evidence from primary care centres, 2006 and 2010. The European Journal of Public Health, 23(1), 103-108.

Hall, K. (2008). The Importance of Financial Literacy. Reserve Bank of Australia.

Karanikolos, M., Mladovsky, P., Cylus, J., Thomson, S., Basu, S., Stuckler, D., ... \& McKee, M. (2013). Financial crisis, austerity, and health in Europe. The Lancet, 381(9874), 1323-1331.

Klehe, U. C., Zikic, J., van Vianen, A. E., Koen, J., \& Buyken, M. (2012). Coping proactively with economic stress: Career adaptability in the face of job insecurity, job loss, unemployment, and underemployment. The role of the economic crisis on occupational stress and wellbeing, 131-176.

Mackinnon, D., \& Derickson, K. D. (2013). From resilience to resourcefulness A critique of resilience policy and activism. Progress in Human Geography, 37(2), 253-270.

Masten, A. S. and Gewirtz, A. H. (2006). Vulnerability and resilience in early child development. Blackwell handbook of early childhood development, 22-43.

Nota, L., Ginevra, M. C., Santilli, S., \& Soresi, S. (2014). Contemporary career construction: The role of career adaptability. In Psycho-social career meta-capacities. Springer International Publishing (pp. 247-263).

Pal, R., Torstensson, H., \& Mattila, H. (2014). Antecedents of organizational resilience in economic crises-an empirical study of Swedish textile and clothing SMEs. International Journal of Production Economics, 147, 410-428. 
Schwartz, S. J., Pantin, H., Coatsworth, D. \& Szapocznik, J. (2007). Addressing the challenges and opportunities for today's youth: Toward an integrative model and its implications for research and intervention. The Journal of Primary Prevention, 28 (2), 117-144.

Tolentino, L. R., Garcia, P. R. J. M., Lu, V. N., Restubog, S. L. D., Bordia, P., \& Plewa, C. (2014). Career adaptation: The relation of adaptability to goal orientation, proactive personality, and career optimism. Journal of Vocational Behavior, 84(1), 39-48.

World Health Organization. (2011). Impact of economic crisis on mental health. Retrieved from http://www.euro.who.int/_data/assets/pdf_file/0008/134999/e94837.pdf on 20 November 2016. 